\title{
Yapısal Aile Sistemleri Yaklaşımı Açısından Türk Sinemasında Aile Filmleri: Münir Özkul ve Adile Naşit Filmleri*
}

\section{Family Films in Turkish Cinema in Terms of Structural Family System Theory: Munir Özkul and Adile Naşit Films}

\author{
Gülşah Tura, ${ }^{\text {a,*** }}$ Berna Gül ${ }^{\text {b }}$ \\ ${ }^{a}$ Dr. Öğr. Üyesi, Kocaeli Üniversitesi, Eğitim Fakültesi, Eğitim Bilimleri Bölümü, 41380, Kocaeli/Türkiye. \\ ORCID: 0000-0002-0611-7993

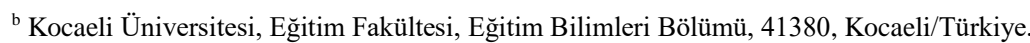 \\ ORCID: 0000-0003-1325-9612
}

\section{MAKALE BİLGísi}

\section{Makale Geçmişi:}

Başvuru tarihi: 01 Șubat 2019

Düzeltme tarihi: 03 Eylül 2019

Kabul tarihi: 17 Eylül 2019

\author{
Anahtar Kelimeler: \\ Aile Terapisi \\ Neşeli Günler \\ Gülen Gözler \\ Bizim Aile \\ Film Analizi
}

\section{A R T ICLE INFO}

\section{Article History:}

Received 01 February 2019

Received in revised form 03 September 2019

Accepted 17 September 2019

\section{Keywords:}

Family Therapy

Cheerful Days

Smilying Eyes

Our Family

Movie Analysis

\section{ÖZ}

Bu çalışmada, Yapısal Aile Sistemleri Yaklaşımının temel kavramlarının açıklanması ve Münir Özkul ile Adile Naşit'in birlikte rol aldığı Yeşilçam sinemasında yer edinmiş üç aile filminin bu kavramlar 1şı̆̆ında incelenmesi amaçlanmıştır. Araştırma amacına uygun şekilde Yapısal Aile Sistemleri Yaklaşımının temel kavramlarından olan aile yapısı, alt sistemler, sınırlar, güç ve ittifak açıklanmış ardından Türk sinemasında aile filmleri arasında yer alan ve Münir Özkul ile Adile Naşit'in birlikte rol aldıkları Neşeli Günler, Gülen Gözler ve Bizim Aile isimli filmler incelenmiştir. Değerlendirme yapılırken doküman analizi yöntemi kullanılmıştır. Yapılan değerlendirme sonucunda Neşeli Günler ve Gülen Gözler filmlerinin aile yapısı, eş alt sistemi, ebeveyn alt sistemi ve güç açısından benzer özellikler gösterdiği bulunmuştur. Üç filmin sadece kardeş alt sistemi açısından ortak özellikler sergilediği görülmüştür.

\section{Giriş}

Yapısal Aile Sistemleri Yaklaşımı 1970'lerde Salvador Minuchin tarafından geliştirilen bir aile terapisi modelidir. $\mathrm{Bu}$ kurama göre aile, toplumsal sistemin bir alt sistemidir. Kendi içinde birtakım alt sistemlerden oluşan aile, belirli gelişimsel görevleri olan ve kendisine ait rol ve kurallarla şekillenen bir yapıdır (Minuchin, 1974: 51). Bir sistem olarak ele alınan ailede sistemlerin genel özelliği gereği, bir üyenin davranışı diğer tüm üyelerin davranışlarıyla ilişkilidir ve aile üyelerinin birbirlerini tamamlayıcı işlevleri vardır (Minuchin, 1974: 13; Nichols, 2013: 210 ). Yapısal Aile Sistemleri Yaklaşımı aile sisteminin parçalarının nasıl

\footnotetext{
*Bu çalışma, 2-5 Mayıs 2018 tarihlerinde Antalya'da düzenlenen 5.Uluslararası Avrasya Eğitim Araştırmaları Kongresi'nde (EJER-2018) bildiri olarak sunulmuştur.

** Sorumlu yazar/Corresponding author.

e-posta: gulsah.tura@kocaeli.edu.tr
} 
etkileșime girdiği, ailede fonksiyonel olmayan iletișim kalıplarının nasıl oluştuğu ve aile sisteminin nasıl kurulduğu üzerine odaklanmaktadır (Bitter, 2014: 234; Gehart, 2016: 126).

Bireyler bir sosyal ağ içerisinde yer alan canlılardır. Bireylerin davranışları yaşadıkları sosyal ă̆ içerisinde oluşan etkileşimin yönüne göre değişmektedir. Ekolojik yaklaşıma göre birey ve sosyal çevresi arasında süregelen karşılıklı bir etkileşim bulunmaktadır. Sosyal ağ içerisinde ev, aile, kültür, alt kültür, toplum, okul, medya gibi sistemler yer almaktadır. Bir sistemde yaşanan bir değişimin diğer sistemleri de etkilediği (Bertalanffy, 2004) görüşünden yola çıkarak makro sistem içerisinde yer alan medyanın aile yapısını, o kültüre ait aile yapısının da medyanın içeriğini etkileyebileceği söylenebilir. Medya kategorisinde yer alan aile filmleri ise aile yapısını yansıtan araçlar arasında yer almaktadır. Yeşilçam sinema tarihinde aileyi konu alan fillmlerde karşımıza çıkan önemli isimler hiç kuşkusuz Münir Özkul ve Adile Naşit'tir. Oynadığı roller gereği sıklıkla aile babasını canlandıran Münir Özkul ve anne rolüyle karşımıza çıkan Adile Naşit'in birlikte rol aldıkları Neşeli Günler, Gülen Gözler ve Bizim Aile adlı filmler, Türk aile yapısı özelliklerini başarılı bir şekilde yansıtan filmler arasında yer almaktadırlar (Yağbasan ve Ateş, 2018: 34).

Filmlerden psikolojide terapi ve öğretim olmak üzere iki farklı amaçla yararlanılmaktadır (Alexander ve Waxman, 2000: 455; Tanner, Haddock, Zimmerman ve Lund, 2003: 355). Terapi amaçlı olarak kullanıldığında filmler, uygulayıcılara bir müdahale yöntemi sağlamaktadır (Shepard ve Brew, 2005: 407). Öğretim amaçlı olarak kullanıldığında ise öğrencilere yaşantısal öğrenme imkanı sağladığı için eğitimi zenginleştirmekte (Shepard ve Brew, 2005: 407) ve ilgili yaklaşımın temel kavramlarını somutlaştırmaktadır (Dermer ve Hutchings, 2000: 164). Türkiye'de aile danışmanlığı eğitiminde aile danışmanlığ kuramlarının ve bu kuramlardaki kavramların Türk kültürüne ve aile yapısına oturtulması konusunda öğrenciler ve eğitimciler zorlanabilmektedir. Türk filmleri çerçevesinde aile danışmanlığı konusunda yapılan çalışmalar oldukça sınırlı sayıdadır (Acar ve Voltan Acar, 2013; Cag ve Voltan Acar, 2015; Y1ldı, 2017). Konu ile ilgili diğer çalışmaların çoğunlukla yabancı filmler kullanılarak gerçekleştirildiği görülmektedir (Bozdağ, 2018; Mert ve Soyer, 2014; Nadir, 2013; Şenol-Durak ve Fişıloğlu, 2007). Bu noktadan hareketle bu araştırmada, Yapısal Aile Sistemleri Yaklaşımı'nın temel kavramları hakkında bilgi verip, Türk aile yapısını yansıttığı düşünülen Neşeli Günler, Gülen Gözler ve Bizim Aile adlı filmlerin bu kavramlar çerçevesinde incelenerek, alan uygulayıcılarına ve öğrencilerine kendi kültürlerinde aile yapısını ilgili yaklaşım çerçevesinde görebilecekleri bilgilerin sunulması amaçlanmıştır. Ayrıca diğer çalışmalardan faklı olarak üç film ele alınmış, her üç filmde de ana kavramlar açısından benzer ve farklı olan noktalara dikkat çekilmesi amaçlanmıştır.

\section{Yöntem}

\subsection{Araştırma Modeli}

$\mathrm{Bu}$ çalışma Münir Özkul ve Aile Naşit'in birlikte rol aldıkları, aile filmleri arasında yer alan Neşeli Günler, Gülen Gözler ve Bizim Aile filmlerinin, Yapısal Aile Sistemleri Yaklaşımı'nın temel kavramları açısından analiz edildiği betimsel bir çalışmadır. Nitel araştırma yöntem ve tekniklerine dayanan bu çalışmada araştırmanın verileri doküman incelemesi yoluyla toplanmıştır. Doküman incelemesi, araştırılması hedeflenen olgu ya da olgular hakkında bilgi veren film, video, fotoğraf, kitap vb. materyallerin analizini içermektedir (Yıldırım ve Şimşek, 2013: 187)

\section{2. İșlem Yolu}

$\mathrm{Bu}$ çalışma Yapısal Aile Sistemleri Yaklaşımı temel kavramları açısından Türk aile filmlerini incelemek amacıyla gerçekleştirilmiştir. Çalışmaya öncelikle Türk sinemasında aile filmlerinde anne ve baba rolleriyle sıklıkla karşılaşılan Münir Özkul ve Adile Naşit'in birlikte rol aldıkları, Türk aile yapısını yansıttığı düşünülen filmler incelenerek başlanmıştır. $\mathrm{Bu}$ filmler iki araştırmacı tarafından ayrı ayrı izlenerek filmlerin Yapısal Aile Sistemleri Yaklaşımına uygunluğu değerlendirilmiştir. Yapılan değerlendirmeye göre Neşeli Günler, Gülen Gözler ve Bizim Aile isimli filmlerin, Türk aile yapısını yansıtması ve yaklaşımın temel kavramlarını barındırması nedeniyle analiz edilmesine karar verilmiştir. Yapısal Aile Sistemleri Yaklaşımı'nın temel kavramları dikkate alınarak iki araştırmacı tarafından ayrı ayrı izlenen filmlerin, yaklaşımın kavramlarıyla ilişkili olduğu düşünülen sahnelerinin dakikaları not edilmiştir. Araştırmacılar arası kodlamatutarlılık katsayısı Miles ve Huberman'ın (1994: 249), Aynı Karar Sayısı/Toplam Karar Sayısı formülüne göre hesaplanmıştır. Formüle göre toplam 21 sahne için elde edilen iç tutarlık katsayısı .95'tir. Araştırmacılar arası kodlama-tutarlık katsayısının .90'dan yüksek çıkması nedeniyle araştırmacılar belirledikleri sahneleri bir araya gelerek analiz etmişlerdir. Filmlerin demografik özelliklerine aşağıda yer verilmiştir. 
Tablo 1. "Neșeli Günler” Filminin Demografik Özellikleri

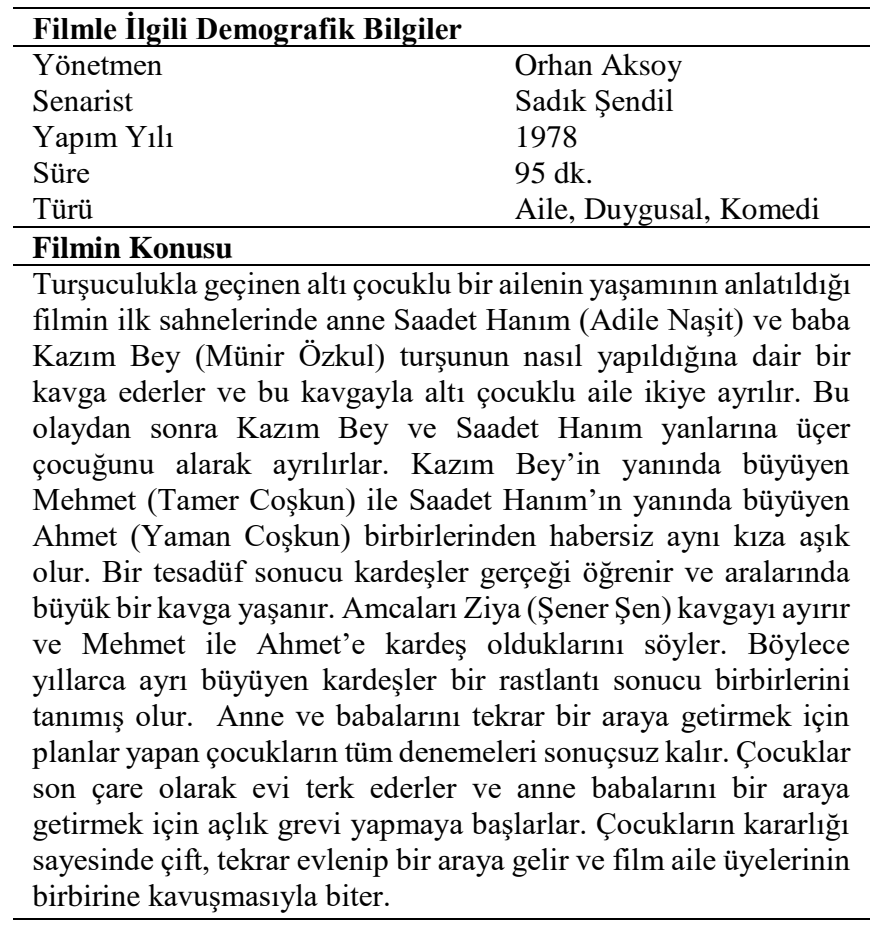

Tablo 2. “Gülen Gözler” Filminin Demografik Özellikleri

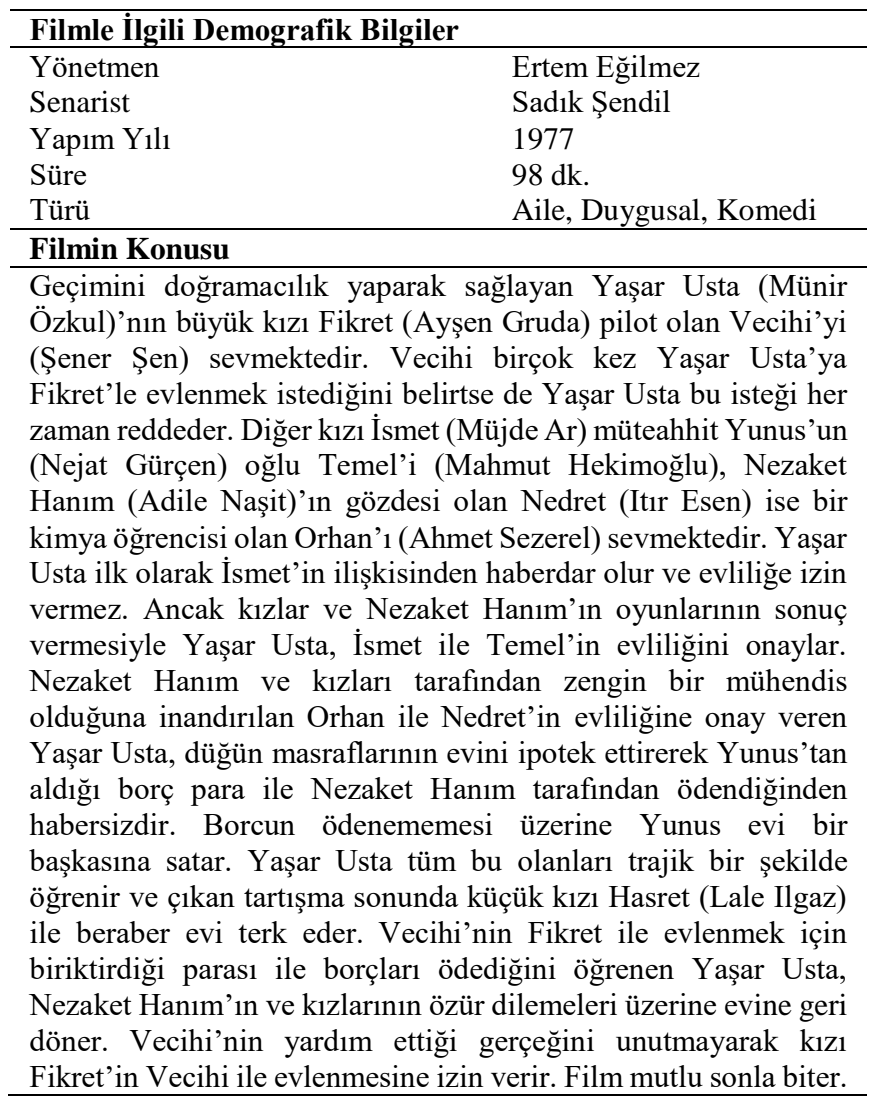

Tablo 3. "Bizim Aile" Filminin Demografik Özellikleri

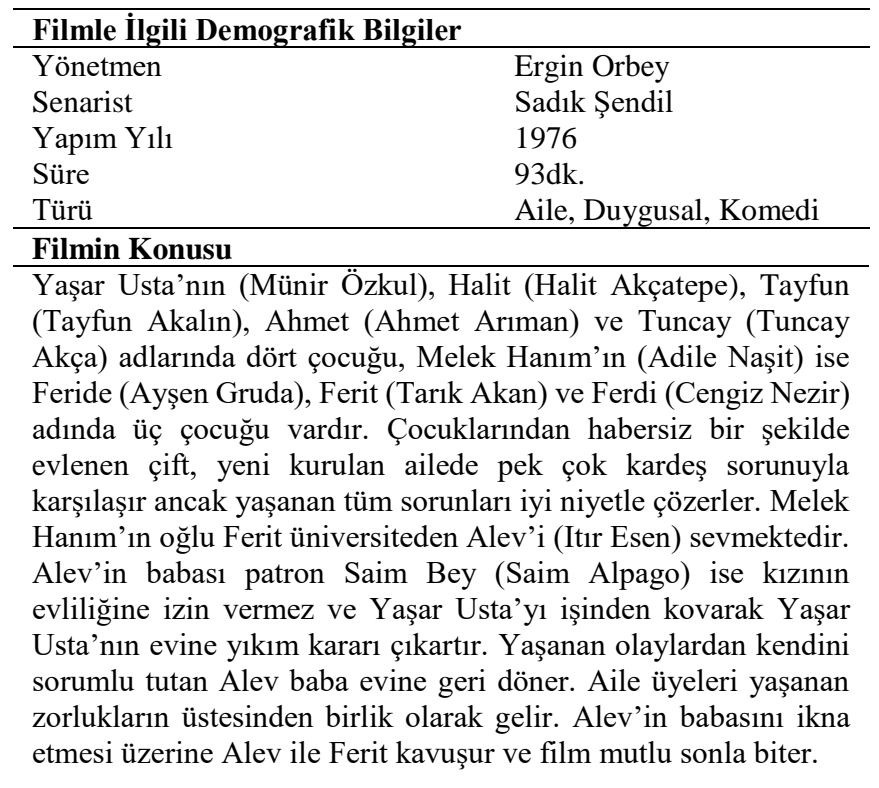

\section{Bulgular ve Yorumlar}

Aile yapısı, alt sistemler (eş, ebeveyn ve kardeş alt sistemi), sınırlar, ittifaklar ve güç kavramları, Yapısal Aile Sistemleri Yaklaşımı'nın temelini oluşturan kavramlardır. Tablo 4'te bu kavramlarla ilişkili olan sahneler, filmlerdeki gösterim yerleri ile birlikte verilmiştir.

Tablo 4. Yapısal Aile Sistemleri Yaklaşımının Kavramlarıyla İlişkili Sahneler ve Filmlerdeki Gösterim Yerleri

\begin{tabular}{|c|c|c|c|}
\hline $\begin{array}{l}\text { Temel } \\
\text { Kavramlar }\end{array}$ & $\begin{array}{l}\text { "Neşeli } \\
\text { Günler" } \\
\text { Filmindeki } \\
\text { Gösterim } \\
\text { Yeri }\end{array}$ & $\begin{array}{l}\text { “Gülen } \\
\text { Gözler" } \\
\text { Filmindeki } \\
\text { Gösterim } \\
\text { Yeri }\end{array}$ & $\begin{array}{l}\text { "Bizim Aile" } \\
\text { Filmindeki } \\
\text { Gösterim } \\
\text { Yeri }\end{array}$ \\
\hline \multirow[t]{2}{*}{ Aile Yap1s1 } & 00'.10"'- & $45^{\prime} .45^{\prime \prime}-$ & 74'.01'” - \\
\hline & $01^{\prime} .05^{\prime \prime}$ & $46^{\prime} .42^{\prime \prime}$ & $75^{\prime} .36^{\prime \prime}$ \\
\hline Eş Alt & 01'.19' - & 78'.24'”- & 43'.29'” - \\
\hline Sistemi & $01 ' .33^{\prime \prime}$ & 80'.19'” & $44^{\prime} .44^{\prime \prime}$ \\
\hline Ebeveyn Alt & 04'.40' - & 79'.33' - & 54'.49'” - \\
\hline Sistemi & $07^{\prime} .02{ }^{\prime}$, & $80^{\prime} .08^{\prime}$, & $55^{\prime} .48^{\prime}$, \\
\hline Kardeş Alt & 78'.30' - & $18^{\prime} .22$ ' - & 59'.00”' - \\
\hline Sistemi & 79'.18', & $22^{\prime} .46^{\prime \prime}$ & $59^{\prime} .31^{\prime \prime}$ \\
\hline \multirow[t]{2}{*}{ Sinırlar } & $07 ' .35$ ' - & $23 ' .17^{\prime \prime}-$ & 79'.03'" - \\
\hline & $08^{\prime} .51^{\prime \prime}$ & $31^{\prime} .38^{\prime \prime}$ & $81^{\prime} .36^{\prime}$ \\
\hline \multirow[t]{2}{*}{ İttifaklar } & 06'.09'” - & 11'.52"' - & 33'.14'" - \\
\hline & $06^{\prime} .53^{\prime}$ & 12'.16’' & $33^{\prime} .57^{\prime \prime}$ \\
\hline \multirow[t]{2}{*}{ Güç } & $01 ' .32$ ' - & $46^{\prime} .57$ ' - & 68'.24'” - \\
\hline & 02'.03', & 48'.13', & 69'.43', \\
\hline
\end{tabular}

Tablo 4'te her üç filmde de Yapısal Aile Sistemleri Yaklaşımı'nın temel kavramlarına dair çeşitli sahnelerin yer aldığı görülmektedir. Aşağıda yaklaşımın temel kavramlarının açıklaması yapılarak sahnelerin bu kavramlar 1şı̆̆ında analizine yer verilmiştir. 
Aile yapısı, aile aktifken ortaya çıkan ve aile bireylerinin etkileşimlerini düzenleyen işlevsel kurallar bütünüdür (Gladding, 2011: 259; Nichols, 2013: 209). Ailenin yap1s1 nasıl kurulduğuna bağlı olarak aileyi olumlu ya da olumsuz etkileyebilmektedir. Bazı ailelerde yap1, aile üyelerinin birbirleriyle etkileşimlerini kolaylaştıracak şekilde iyi organize edilebilmekteyken bazılarında ise aile içi etkileşimleri sağlayacak belirgin bir yapı kurulamamaktadır (Figley ve Nelson, 1990: 226; Gladding, 2011: 259). Sağlıklı aileler, aile yapısını yeniden yapılayabilecek esnekliğe sahip olduğu için yaşamın stresleriyle baş ederek aile bütünlüğünün devamını sağlayacak uyumu geliştirilebilmektedir (Goldenberg ve Goldenberg, 2008: 4). Aile yapısının sağlıksız kurulduğu durumlarda ise aile iyi organize olamadığı için kriz durumlarını sağlıklı atlatamamaktadir.

"Neșeli Günler", "Gülen Gözler" ve "Bizim Aile" Filmlerinden Bazı Sahnelerin Aile Yapısı Açısından Değerlendirilmesi

\section{Neşeli Günler: Saadet Hanım ve Kazım Bey'in Turşu Dükkanındaki Kavgaları.}

Saadet Hanım ve Kazım Bey turșu dükkanındayken içeriye bir müşteri gelir. Kazım Bey Saadet Hanım'a "Şşst. Nuri Bey'e bak." diye bağırır. Saadet Hanım "Sen bak! Görmüyor musun? Hesap yapıyorum. Dört tane elim yok ya!" diye bağırarak karşılık verir. Tartışma giderek artar ve şiddetlenir.

Gülen Gözler: Nezaket Hanım ve Kızları Orhan'ın Öğrenci Olduğunu Yaşar Bey'den Saklar.

Nedret, Orhan'la evlenmek istemektedir. Nezaket Hanım yaptıkları plan gereği Orhan'ın Nedret'i tanıdığını ve henüz okulunu bitirmediğini Yaşar Bey'den saklar. Nedret annesine babası için "Bir bilse Orhan'ın kim olduğunu." der ve Nezaket Hanım'in cevabl "Bir bilse de hepimizi kesse." olur.

\section{Bizim Aile: Kardeșler Aileye Destek Olmaya Bașlar.}

Yaşar Bey'i ișten atılması üzerine aile maddi zorluklar yașamaktadır. Sporcu oğlu Ahmet transfer olmuștur ve kazandiğl transfer parasinin hepsini "O para sizin." diyerek anne ve babasina vermiştir. Bir sonraki sahnede ise ailesinden habersiz bir fabrikaya giren Tayfun kazandi ̆̆ tüm parasiyla eve erzak getirir. Bunun üzerine Yaşar Bey Melek Hanım'a "Bizim çocuklara bir hal oldu hanım." der. Melek Hanım ise "Büyüdüler Yaşar Bey, büyüdüler." diyerek karşılık verir.

Neşeli Günler filminde Saadet Hanım ve Kazım Bey çifti dükkana gelen müşteriye yardım edilmesi konusunda bu görevi kimin yapacağına dair bir tartışmaya girmektedirler. Tartışmaları ise her zaman olduğu gibi kavga ile sonlanmaktadır. Filmdeki bu sahneden aile yapısının sağlıklı olmadığının önemli işaretlerinden biri olan her konuda sürekli tartışan çiftin ufak bir iş bölümünde bile kavga etmeleri görülür. Dolayısıyla bu filmdeki aile yapısının eşlerin birbirleriyle etkileşimini kolaylaştıracak şekilde oluşmadığı yani sağlıklı kurulmadığı söylenebilir. Benzer şekilde Gülen Gözler filminde de Nezaket Hanım'ın, eşinin vereceği tepkiden korkarak gerçekleri sakladığı göze çarpmaktadır. Bu filmdeki aile yapısının da işlevsel olmadığ ve aile üyelerinin kriz durumunu birbirine yalan söyleyerek aşmaya çalıştığı ifade edilebilir. Her iki filmden farklı olarak Bizim Aile filminde ise maddi zorluk yaşayan aileye çocukların destek olduğu görülmektedir. Yapısal Aile
Sistemleri Yaklaşımı'na göre sağlıklı yapı kuran aileler, yaşam içinde karşılaştıkları problemlerle baş edebilecek esnekliğe sahip olup aile yapısını yeniden yapılayabilmektedirler. Dolayısıyla Bizim Aile filminde eșlerin ikinci evliliği olsa da ve filmin başında Yaşar Bey ve Melek Hanım'ın çocukları kardeş olarak birbirlerini kabul etmekte biraz zorlansa da aile yapısının sağlıklı kurulduğu söylenebilir.

\section{Alt Sistemler}

Ailede her bir birey bir alt sistemi oluşturmaktadır. Aile, alt sistemler aracılığıyla farklılaşmakta ve işlevlerini yerine getirmektedir (Minuchin, Colapinto ve Minuchin, 2007: 20). Ailedeki her bir birey bir alt sistem olduğu gibi aile üyeleri arasında kurulan alt sistemler de bulunmaktadir. Alt sistemlerde bireylerin kendilerine ait rolleri, görevleri ve statüleri vardır ve bir bireyin farklı alt sistemlerdeki rolleri, görevleri ve statüleri farklı olabilir. Çekirdek ailede en belirgin alt sistemler karı-koca, ebeveyn-çocuk ve kardeş alt sistemleridir (Sharf, 2010: 546). Minuchin'e göre (1974) aile sistemini oluşturan tüm alt sistemler iç içe bir yap1 sergilemektedir. $\mathrm{Bu}$ nedenle bir alt sistemde yaşanan problem diğer alt sistemleri de kolaylikla etkileyebilmektedir.

Eş alt sistemi iki yetişkinin bir aile oluşturmak için bir araya gelmesiyle oluşmaktadır ve diğer alt sistemler açısından merkezi konumdadır. Eş alt-sisteminin, ailenin işlevselliğini sağlamak amaciyla belirli görevleri bulunmaktadır. Üyeler bu görevleri yerine getirirken karşılıklı uyum ve tamamlayıcılık becerilerini kullanmaktadırlar (Minuchin, 1974: 56). Eş alt sisteminde bir takım problemlerin olduğu ailelerde, kardeş ilişkileri ve ebeveynlik rolleri de kolaylıkla bozulabilmektedir (Brody, Stoneman ve McCoy, 1994: 772). Dolayısıyla bu alt sistemin güçlü ve sağlıklı kurulması, ailenin sağlıklı devamı için gereklidir. Eşler birbirlerini tanır, kabul eder, ihtiyaçlarını karşılar ve rollerini tamamlarlarsa ailenin devamlılığı uzun soluklu olmaktadır.

Çocukların doğumu ile birlikte eşler ebeveyn alt sistemini oluşturmaktadırlar. Ebeveyn alt sistemi, çocukların bakımı, beslenmesi, eğitimi ve disiplininden sorumlu olan alt sistemdir (Whiteside, 1994: 87). Ebeveyn alt sistemi çocuklarının fiziksel bakımını karşılarken, aynı zamanda onların sosyal becerilerinin gelişmesine ve sağlıklı bir benlik algısı oluşturmalarına da katkı sunmaktadırlar (Goldenberg ve Goldenberg, 2008: 88). Kardeş alt sistemi ise çocukların yaşıt ilişskileri yaşadığı ilk sosyal laboratuvardır. Bu alt sistemde kardeşler birbirlerini desteklemeyi, korumayı ve birbiriyle işbirliği içinde olmayı öğrenebileceğ gibi birbirleriyle rekabet etmeyi de öğrenebilirler (Minuchin, 1974: 59). Dolayısıyla çocukların kardeş alt-sistemlerinde aldıkları roller, yaşamlarının sonraki dönemlerinde alacakları rolleri de şekillendirmektedir.

"Neşeli Günler", "Gülen Gözler" ve "Bizim Aile" Filmlerinden Bazı Sahnelerin Eş Alt Sistemi Açısından Değerlendirilmesi

\section{Neșeli Günler: Saadet Hanım ve Kazım Bey Kavga Ederler.}

Saadet Hanım ve Kazım Bey müşterinin yanında tartışırlar. Kazım Bey Saadet Hanım'a bağırarak "Bana bak. Sana kaç defa elalemin yanında bana cevap verme demedim mi?" der ve Saadet Hanım "Dedin" diyerek bağırarak cevap verir. "Peki öyleyse niye dilini 
tutmuyorsun be kadın" diyerek kızan Kazım Bey'e Saadet Hanım "Niye tutayım. Sen bağır ben susayım oh ne ala." cevabinı verir.

\section{Gülen Gözler: Yaşar Bey Gerçekleri Ö̆̆renir.}

Ipotek kaldırılamadı ̆̆ için evi satın alan kişi eve aniden gelir ve Nezaket Hanım'ın, düğün masrafları için Yunus'tan borç aldiğını, ödeyemeyince de evi ipotek ettiğini Yaşar Bey'e anlatır. Annelerini savunmaya çalışan kızlarına da sinirlenen ve vurmaya kalkan Yaşar Bey'e Nezaket Hanım: "Dokunma kızıma. Amma uzattın. Sattlysam kendi evimi sattım." der.

Bizim Aile: Melek Hanım ve Yaşar Bey Birlikte Sofra Hazırlar.

Melek Hanım ve Yașar Bey evdeki masraflar planlamaktadırlar. İşleri bittikten sonra Melek Hanım "Sofrayı kursak mi?" diyerek kızı Feride'ye bakar. Feride ayna karşısında kendisiyle ilgilendiği için söylenenlerin farkına bile varmaz. Diğer çocuklarına bakan Melek Hanım'a Kazım Bey "Ne yapalım, bari biz kuralım." diyerek eşiyle birlikte sofra hazırlar.

Neşeli Günler fillminin bu sahnesinde, filmin ilerleyen sahnelerinden de anlaşılacağı gibi Kazım Bey ve Nezaket Hanım arasında sürekli devam eden bir çekişme söz konusudur ve çift neredeyse hiçbir ortak noktada buluşamamaktadır. Bu durum ise eş alt sisteminin, ailenin sağlıklı devamını destekleyecek yönde kurulmadığını düşündürmektedir. Gülen Gözler filminde de benzer şekilde eş alt sisteminin tamamlayıcılık ve uyum özelliğine sahip olmadığı görülmektedir. Nitekim karşılaşılan bir kriz anında Nezaket Hanım'ın bunu krizi eşinden gizleyerek çözmeye çalışması ve kendi evini sattığını söyleyerek evin eşlerin ortak malı olmadığını vurgulaması bunun bir göstergesi olarak düşünülebilir. Bizim Aile filminde ise eşler, sofra hazırlama gibi bir etkinliği, kriz oluşmasına izin vermeden birlikte hazırlayarak çözme yolunu seçmişlerdir. Bu durum da eş alt sisteminin uyum içerisinde olduğunu, eşlerin birbirlerini destekleyen pozitif bir iletişim içinde olduğunu göstermektedir.

"Neşeli Günler”, “Gülen Gözler” ve "Bizim Aile” Filmlerinden Bazı Sahnelerin Ebeveyn Alt Sistemi Açısından Değerlendirilmesi

\section{Neşeli Günler: Kazım Bey ve Saadet Hanım Ayrılırlar.}

Kazım Bey ve Saadet Hanım turşu suyunun limonla mı yoksa sirkeyle mi daha iyi yapıldiğ tartışmaktadırlar. Dozu git gide yükselen tartışmada çifti çocukları ayırmaya çalışır. Çocukların çabalarının başarısız kaldı̆̆ tartışma sonunda Kazım Bey ü̧̧ çocuğunu alıp gider ve Saadet Hanım da diğer ü̧̧ çocuğuyla evde kalır.

\section{Gülen Gözler: Yaşar Bey ile Kızları Tartışır.}

Evin satıldığını öğrenen Yaşar Bey’e kızı Nedret “Benim için yaptı. Anneme kızma." der. Yaşar Bey ise "Yazıklar olsun ben sizin için çabalayayım siz benim arkamdan iş çevirin." cevabını verir. Tartışmanın devamında İsmet ise "Bakacaksın tabi. Babamız değil misin?" diyerek babasına bağırır. Fikret' in "Ne bağırıyorsun? Dünyaya getirmeseydin." cümlesinin ardından Nedret de "Eve bir ekmek getirmekle baba olunmaz." der.

Bizim Aile: Feride Yaşar Bey'e “Baba” Der.

Dügün sonrasinda evinden ayrlmasi gereken Feride annesi ve kardeşleriyle vedalaşır. Sira Yaşar Bey'le vedalaşmasına gelince o zamana kadar baba kelimesini kullanmadığ Yaşar Bey'e "Allaha ismarladık baba." der ve Kazım Bey de "Güle güle kızım.” diyerek cevap verir.

Ebeveyn alt sisteminin çocukların gelişimsel ihtiyaçlarını karşılama görevinin yanında aile sisteminin devamını sağlayacak sağlıklı kararları vermek gibi sorumluluğu da bulunmaktadır. Ancak Neşeli Günler filmindeki bu sahne ebeveynlerin ailenin devamını sağlayamadığını, çocukların yanında kavga edip ayrılarak çocukların duygusal gelişimlerini de olumsuz etkilediklerini göstermektedir. Gülen Gözler filminde ise çocukların babalarına karşı öfke dolu ifadeler kullanmaları baba figürünün çocuklar tarafından olumsuz algılandığını göstermektedir. $\mathrm{Bu}$ bilgilere dayanarak ebeveyn alt sisteminin sağlıklı kurulmadığ 1 söylenebilir. Bizim Aile filminde ise tekrar evlilikle kurulan bir aile olmasına rağmen, ebeveyn alt sisteminin sağlıklı kurulduğu görülmektedir. Filmin bu sahnesinde evin kızı Feride'nin Yaşar Bey'e "baba" diyerek hitap etmesinin altında, filmin önceki sahnelerinde görülen Yaşar Bey'in tüm evlilik sürecinde Feride'ye destek olması ve ihtiyaçlarını karşılaması bulunmaktadır.

"Neşeli Günler", "Gülen Gözler" ve "Bizim Aile" Filmlerinden Bazı Sahnelerin Kardeş Alt Sistemi Açısından Değerlendirilmesi

\section{Neșeli Günler: Kardeșler Anne Babalarını Barıștırmak İçin Açlık Grevi Yapar.}

Anne babalarının kardeşler bir araya geldikten sonra da devam eden tartışmalarına dayanamayan ve bir daha ayrılmak istemeyen kardeşler hazırladıkları pankartlarla bir meydanda açlık grevine başlarlar.

Gülen Gözler: Kardeşler Odalarında Hep Birlikte Şarkı Söyler.

İsmet'e görücü gelmiştir. Ancak Ismet gelen bu görücüyle evlenmek istememektedir. Misafirlerin gitmesi üzerine odalarında toplanan beş kı kardeş evlilikle ilgili ortak sıkıntılarını paylaşır ve hep birlikte "Beterin Beteri Var" adlı şarkıyı söylerler.

\section{Ferit'in Kavga Sonrası Eve Gelişi}

Ferit, Alev'in babasinın adamları tarafindan dövülür. Eli yüzü kanll bir halde eve gelen Ferit'i gören annesi ve kardeşleri telaşlanır. Bu duruma üzülen Tayfun o zamana kadar ağabey diyerek seslenmediği Ferit'e "Geçmiş olsun Ferit Ăgabey." der. Ahmet de "Elimizden bir şey gelirse yapalım ağabey." diyerek Ferit'e destek olur.

Yapısal Aile Sistemleri Yaklaşımı'na göre kardeş alt sistemi sağlıklı kurulursa, kardeşler birbirlerini desteklemeyi, işbirliği içinde çalışmayı ve paylaşmayı öğrenirler. Her üç filmde de kardeşlerin ortak amaç için hareket etmeleri, benzer duyguları yaşamaları ve zor anlarda birbirlerine destek olmalarından bu alt sistemin sağlıklı kurulduğu sonucuna ulaşılabilir.

\section{Sinırlar}

Ailede sınırlar, psikolojik, duygusal, davranışsal ve ilişkisel boyutlarda aileyi belirleyen, aileyi diğer ailelerden ayıran ve aile üyelerinin birbirleriyle olan temasını düzenleyen görünmez çizgilerdir (Gladding, 2011: 261; Nichols, 2013: 211). Ailede her bir alt sistem, kendi içinde ilişkilerin niteliğini belirleyen sınırlarla çevrilidir. Ailenin işlevsel olabilmesi için alt sistem sınırlarının açık ve net olması gerekmektedir (Minuchin, 1974: 54). Bir başka deyişle 
sağlıklı ailede sınırlar, üyeler arasındaki ilişkiyi geliştirici nitelikte olmalı, sistemlerin birbirleriyle etkileşimini olumlu yönde desteklemelidir.

Yapısal Aile Sistemleri Yaklaşımı'nda katı, belirsiz ve belirgin olmak üzere üç tür sınır bulunmaktadır. Katı sınıra sahip ailelerde üyeler ve alt sistemler birbirlerinden uzaktır. Üyeler arasında sağlıklı iletişim olmadığı için aile üyeleri birbirlerinden duygusal olarak kopuktur (Gladding, 2011; 261; White, Klein ve Martin, 2015: 333). Katı sınırlara sahip ailelerin tam tersine belirsiz sinırlara sahip ailelerde üyeler arasında iç içe geçmişlik hakimdir. Aile üyelerinde bağımsızlık ve farklılaşma yerine bağımlılık bulunmaktadır. Belirgin sinırlara sahip ailelerde ise üyeler kendi bireyselliklerini korur ve ait olma duygusunu yaşarlar. Üyelerin birbirleriyle kurdukları iletişimle alt sistemler arasında bulunan iletişim açık ve sağlıklıdır. Herhangi bir problemle karşılaşıldığında üyelerin birbirlerinden yardım alacaklarını bilmeleri, bireylere güven vermekte ve biz duygusunun oluşumunu desteklemektedir (Goldenberg ve Goldenberg, 2008: 88; Rasheed, Rasheed ve Maley, 2011: 218).

"Neşeli Günler", “Gülen Gözler" ve "Bizim Aile” Filmlerinden Bazı Sahnelerin Sınırlar Açısından Değerlendirilmesi

\section{Neşeli Günler: Kazım Bey çocuklarına "Hem Babanız Hem de Ananızım" der.}

Çocuklarına sabah kahvaltısı hazırlayan Kazım Bey bir yandan da gömleğinin düğmesi sökülen oğlu Ömer'in düğmesini dikmeye çalışmaktadır. Ömer'in "Baba bıraksan da artık kendi sökügüumüzü kendimiz diksek. Kocaman adam olduk." demesi üzerine Kazım Bey "Olmaz. Kaç defa söyledim. Sizin hem babanız hem de ananızım. Bu iş de bana düşer." diyerek karşılık verir.

\section{Gülen Gözler: İsmet Temel ile Evlenmek İstemektedir.}

İsmet Temel ile evlenme isteğini babasına açıklar. Kızına büyük bir tepki gösteren Yaşar Usta, "Ben yaşadığım sürece bu evde benim dediğim olur." diyerek bu evliliği reddeder. Nezaket Hanım ve klzlarl, bir plan kurar. Ismet'in evden kaçtığına Yaşar Usta'yı inandırır. İlk günlerdeki öfkesi geçen Yaşar Usta, bir gece evde içki içtiği bir akşam yemeğinde kızının evde saklandığını ögrenir. Duygularına hakim olamaz ve kizına kavuştuğu için çok mutlu olur. Bu olay sonrasinda Ismet'in Temel ile evliliğine izin verir.

\section{Bizim Aile: Tüm Aile Bir Geceyi Bahçede Geçirir.}

Evlerinin mühürlenmesi üzerine tüm aile esyaların alarak bahçeye yerleşir ve geceyi bahçedeki yataklarında uyuyarak geçirir. Ertesi günün sabahında olumsuz duygular içinde olan çocuklarına Yaşar Bey "Ne olmuş yani evden atılmışsak? Asıl şimdi daha güçlü olmamız lazım. İşimize dört elle sarılmamız lazım. Bize kötülük edenlere mağlup edilmeyeceğimizi ancak böyle anlatabiliriz" der. Tüm kardeșler "Babamı haklı kimse bizi yıkamaz." diyerek güne başlarlar. Tüm aile üyelerinin yüzü gülmektedir.

Belirsiz sınırlarda aile üyeleri arasında bir çeşit iç içe geçmişlik bulunmaktadır. Üyelerin rol ve görevleri değiştiğinden aile bireylerinin özerklikleri desteklenmez, aksine bağımlılıklar oluşmaktadır. Neşeli Günler filminin bu sahnesinde Kazım Bey'in hem anne hem de baba rolünü üstlendiği ve oğlunun kendi ihtiyaçlarını karşılamasına izin vermediği görülmektedir. Bu durum üyeler arasındaki sınırın belirsiz olduğunu düșündürmektedir. Gülen Gözler filmindeki sahneden de Yaşar Usta ve kızları arasında katı sınırların olduğu sonucuna varılabilir. Katı sınırları olan ailelerde üyeler kullandıkları sağlıksız iletişim nedeniyle birbirleriyle yakın ilişki kurmada güçlük yaşamaktadırlar. İlişkiler ancak dışarıdan bir müdahale olduğu takdirde esnetilebilmektedir. Nitekim İsmet'in evliliğini kabul ettirmek için Nezaket Hanım ve diğer kızları tarafından Yaşar Usta'ya oynanan oyun, bunun bir göstergesidir. Belirgin sınırları olan ailelerde üyeler özerkliklerini koruyabilirken aileye dair biz duygusuna sahiptirler. Üyelerin birbirleriyle iletişimleri açık ve destekleyicidir. Bizim Aile filminin bu sahnesinden aile üyelerinin yaşanan kriz sonrasında birbirlerine destek verecek şekilde biz duygusuna sahip olduğu görülmektedir. Bu durum da üyeler arasında kurulan sınırın belirgin olduğunu düşündürmektedir.

\section{Ittifaklar}

İttifak, aile sistemi içinde belli bazı işlevleri yüklenmiş bir kişinin karşısında olmak veya yanında yer almaktır (Sharf, 2011: 547). Ailelerde en yaygın ittifak biçimleri koalisyon ve üçgenleşmedir. Üçgenlerde ebeveynler, çocuğu kendilerinden taraf olmaya zorlamaktadirlar. Çocuk bir ebeveynin tarafında olduğunda diğer ebeveyn bunu saldırı ya da ihanet olarak görebilmektedir (Nazl1, 2016: 114). Anne babası arasında seçim yapmaya zorlandığ 1 durumlarda kararı ne olursa olsun duygusal yönden olumsuz etkilenebilmektedir.

Koalisyon ise belirli aile üyelerinin ailenin bir üyesine karşı birleşmesidir. $\mathrm{Bu}$ birleşme aynı amacı paylaşan aile üyelerinin diğer aile üye veya üyelerine karşı olması temelinde olduğu için ailenin bazı üyeleri koalisyonun dışında kalmaktadır (Gladding, 2011: 262; Sharf, 2010: 547). Koalisyonlar, her ailede belli düzeylerde gerçekleşebilmektedir. Ancak ebeveynin otoritesini çocuğunun gelişimi için kullanmasını engellediği ve aileyi işlevsellikten uzaklaştırdığı durumlarda sorun yaratabilmektedir.

"Neşeli Günler”, “Gülen Gözler" ve "Bizim Aile" Filmlerinden Bazı Sahnelerin İttifaklar Açısından Değerlendirilmesi

\section{Neşeli Günler: Saadet hanım çocuklarına “Anasını Seven Benimle Kalsin” der.}

Kazım Bey ve Saadet Hanım'ın kavgalarını çocukları ayırmaya çalışır. Üç çocuk babasını ve diğer üç çocuk da annesini yatıştırmaya çalışırken Nezaket Hanım Kazım Bey'e "Defol git bu evden." der. Yanındaki üç çocuğunu da çekeleyerek kapıdan çıkmaya çalışan Kazım Bey'in "Çocuklarımın hepsi beni ister." sözü üzerine Saadet Hanım "Yavrularım sakın bu deliye uymayın. Anasın seven benimle kalsin" der.

Gülen Gözler: İsmet ve Annesi Görücüler Hakkında Konuşur.

Akşam gelecek olan görücüler hakkında İsmet annesine "Ya babam gelenlere evet derse ne olacak?" diye sorar. Nezaket Hanım ise "Aman İsmet. Babanı tanımazmıs gibi konuşma. O istediği kadar evet desin. Biz ne yapar ne eder istediğimizi yaptırırız." der. 


\section{Bizim Aile: Tüm Aile Birlikte Akşam Yemeği Yer.}

Tüm aile yemek için sofradadır. Melek Hanım'ın oğlu Ferit tuzu almak için uzanır. Tam o sırada tuzluğu Yaşar Bey'in oğlu Halit kapar. Yemeğine tuzunu attıktan sonra tuzluğu Ferit yerine kendi kardeşi Tayfun'a uzatır. Tayfun'un elinden tuzluğu çeken Ferit, kullandiktan sonra tuzluğu kendi kardeşi Feride'nin yanına bırakır.

Neşeli Günler filminde Saadet Hanım'ın çocuklarını seçime zorlaması bir üçgenleşme olarak düşünülebilir. Nitekim üçgenlerde ebeveynler çocukları kendi tarafında olmaya zorlamaktadırlar. Gülen Gözler filminde ise anne k1z koalisyonunun kurulduğu görülmektedir. Koalisyon durumunda aynı amacı paylaşan üyeler, amaçlarının gerçekleşmesini olumsuz etkileyebileceğini düşündüğü aile üyesini koalisyonun dışında bırakmaktadır. Bu sahnede de Nezaket Hanım'ın biz ne yapar eder istediğimizi yaptırırız sözünden Yaşar Bey’i saf dışı bıraktıkları görülmektedir. Bizim Aile filminin bu sahnesi tekrar evlilikle kurulan ailenin ilk zamanlarını anlatan sahneler arasındadır. Anne babalarının evliliklerini kabullenmeyen Melek Hanım'ın ve Yaşar Bey'in çocukları arasında koalisyonlar oluştuğu görülmektedir. Her iki kardeş grubu da yeni tanıştıkları kardeş grubunu ortak amacı paylaşmadıkları düşüncesiyle dışarıda bırakmaktadır. Ancak filmin ilerleyen sahnelerinde bu koalisyonların ortadan kalktığı ve kardeşlerin birbirlerini kabul ettiği görülmektedir.

Güç

Güç, ailede sorumluluk ve otoritenin hangi bireyde olduğunu, kararların kim tarafindan alınacağını belirlemektedir (Sharf, 2010: 572; Lee, 2011: 231). İşlevsel ailelerde ise anne babaların çocuklarına göre daha fazla güce sahip olması gerekmektedir. Sağlıssı ailelerdeyse, aile sistemini oluşturan hiyerarşik yapılanmada bazı farklılıklar olduğu gözlenmektedir (Minuchin, 1981: 131). Anne ve babaların çocuklarını disipline etmek için yeteri kadar güce sahip olmamalarının yanı sıra gücün eşlerden birinin üzerinde yoğunlaşması da ailede güç dengesizlikleri yaratabilmektedir.

"Neşeli Günler", “Gülen Gözler” ve "Bizim Aile” Filmlerinden Bazı Sahnelerin Güç Açısından Değerlendirilmesi

\section{Neşeli Günler: Kazım Bey ve Saadet Hanım Turşu Suyı İçin Kavga Eder.}

Kazım Bey ve Saadet Hanım turşu suyunun nasıl yapıldı ̆̆ konusunda anlaşamamaktadır. Saadet Hanım "Sirkeyle olur!" diye bağırırken Kazım Bey ise "Limonla olur!" diye bağırmaktadır.

\section{Gülen Gözler: Yaşar Usta, Nedret'in evliliğine karar verir.}

Tüm aile sofradadır. Yaşar Usta akşam kendisine görücü gelecek olan Nedret hakkında ailenin diğer üyeleriyle konuşmaktadır. Yaşar Usta'nın "Bir gelsin bakalım, görelim. Gözüm tutarsa veririm.” sözü üzerine Nedret "Baba benim fikrimi sormayacak misın?" der. Yaşar Usta ise "Tabi sormayacağım. Bu evde ben ne dersem o olur." der.

\section{Bizim Aile: Yaşar Bey ve Ferit Sohbet Eder.}

Yaşar Bey'in işten atılması olayında Ferit kendini suçlu hisseder. Yaşar Bey'e tek çözümün Alev'le birlikte evden gitmeleri olduğunu söyler. Bu kararı kabul etmeyen Yaşar Bey şu sözlerle Ferit'e karşıllk verir: "Anlıyorum gençsin, yüreklisin ama izin ver de ben de babalık görevimi yerine getireyim. Hadi bakalım sen de bu laflart söylememiş ol. Seni de kardeşlerini de kendi evlatlarımdan zerre kadar ayırmadığımı iyi bil.",

Neşeli Günler fillminde eşlerin turşunun nasıl yapılacağıyla ilgili bir karara varma noktasında büyük bir güç yarışına girdikleri görülmektedir. Nitekim Yapısal Aile Sistemleri Yaklaşımı'nda kararların kim tarafindan verileceği, aile sisteminde gücü işaret etmektedir. Dolayısıyla eşlerin bu noktada gücü kendi ellerinde tutma gibi bir eğilimleri olduğundan söz edilebilir. Gülen Gözler Filminde ise Yaşar Bey'in "Ben ne dersem o olur" sözüyle gücü kendi elinde tutmaya çalıştığı görülmektedir. Ancak Yapısal Aile Sistemleri Yaklaşımı'na göre ebeveynlerin çocuklarına göre daha fazla güce sahip olmasının yanında bu gücün ebeveynler arasında sağlıklı dengelenmesi de önemlidir. Bu sahneden yola çıkarak filmde gücün işlevsel dağılmadığından bahsedilebilir. Bizim Aile filminde Ferit'in aldığı karara karşı çıkan Yaşar Bey’in, kararların verilmesi noktasında ebeveyn olma gücünü kullandığı görülmektedir. Yaşar Bey'in sahip olduğu gücü, ailenin devamı yönünde pozitif bir amaçla kullandığg 1 görülmektedir.

\section{Sonuç ve Öneriler}

Neşeli Günler, Gülen Gözler ve Bizim Aile filmleri Yapısal Aile Sistemleri Yaklaşımı'na göre incelendiğinde, Neşeli Günler ve Gülen Gözler filmlerindeki aile yapılarının aile sistemini destekler nitelikte sağlıklı kurulmadığ görülmüştür. Bizim Aile filminde ise aile üyeleri ve alt sistemlerin uyum içinde etkileşerek kriz anlarını aile sisteminin devamını sağlayacak şekilde atlatabildikleri için aile yapısının sağlıklı kurulduğu düşünülmüştür.

Her üç filmde de kardeş alt sistemi açısından benzer özellikler gözlenmiştir. Filmlerde kardeşler arası ilişkilerin içten, sıcak ve birbirini destekler niteliktedir. Bu durum da kardeş alt sistemin söz konusu filmlerde sağlıklı kurulduğunu düşündürmektedir.

$\mathrm{Bu}$ çalışmanın sonuçları bir bütün olarak değerlendirildiğinde, filmlerde ele alınan ailelerin alt sistemleri arasındaki ilişkinin açık şekilde kurulamadığ durumlarda, ailelerin kriz anlarını sağlıklı atlatamadığı ve dolayısıyla aile sisteminin olumsuz etkilendiği gözlenmiştir. Özellikle ailenin kurulmasında temel olan eş alt sistemi, ailedeki üyelerin tutumlarını etkilemektedir. Eş alt sistemi sağlıklı bir şekilde kurulduğunda diğer alt sistemlerde karşılaşılan problemlerin de kolaylıkla çözüldüğü görülmüştür. Eş alt sisteminin sağlıklı kurulmasının temelinde eşlerin birbirlerinin bir birey olarak kabul etmesi ve birbirlerine sayg1 duyması yer almaktadır. Örnek olarak Gülen Gözler filminde ailede otorite figürü baba iken bütün kardeşlerin ve annenin, babaya karşı koalisyon kurduğu ve anne tarafindan desteklenmeyen baba otoritesinin de aile ilişkilerinde etkili olamadığı görülmektedir.

Sınırlar açısından bakıldığında ise incelenen filmlerde sınırların belirsiz ya da katı olduğu ailelerde, üyelerin yaşanan zor durumlarla baş etme becerilerinin iyi olmadığ görülmüştür. Alt sistemler arasında kurulan belirgin sınırların ise Bizim Aile filminde olduğu gibi üyelerin yaşanılan krizleri sağlıklı atlatmalarına katkı sağladığı gözlemlenmiştir. Sonuç olarak Neşeli Günler, Gülen Gözler ve Bizim Aile filmlerinin Yapısal Aile Sistemleri Yaklaşımı'na ilişskin birçok kavramı içerdiğini ve yaklaşımın 
birçok hipotezini destekleyecek örneklerin filmlerin sahnelerinde gözler önüne serildiğini söylemek mümkündür. $\mathrm{Bu}$ sebeple gerçekleştirilen çalışmanın Yapısal Aile Sistemleri Yaklaşımı'nı Türk aile yapısı bağlamında fark etmek isteyen alan çalışanlarına katkı sağlayabileceği düşünülmektedir.

Ayrıca Türk aile yapısını yansıttığg düşünülen Neşeli Günler, Bizim Aile ve Gülen Gözler filmleri Yapısal Aile Sistemleri Yaklaşımı kavramları çerçevesinde incelenmiş ve aile danışmanlığı eğitimlerinde yararlanılabilecek filmler olarak değerlendirilmiştir. İleride yapılacak çalışmalarda Yapısal Aile Sistemleri Yaklaşımına yönelik güncel ve popüler Türk filmleri incelenebilir. Ayrıca bu çalışmada ele alınan Münir Özkul ve Adile Naşit filmleri farklı aile terapilerinin kavramları çerçevesinde incelenebilir.

\section{Kaynakça}

Acar, T. \& Voltan Acar, N. (2013). Babam ve Oğlum Filmi'nin çok kuşaklı/kuşaklararası aile terapisinin temel kavramları açısından değerlendirilmesi. Kuram ve Uygulamada Ĕgitim Bilimleri, 13(1), 37-53.

Alexander, M. \& Waxman, D. (2000). Cinemeducation: teaching family systems through the movies. Families. Systems \& Health: The Journal of Collaborative Family Health Care, 18(4), 455-466. doi: $10.1037 / \mathrm{h} 0091869$

Bertalanffy, V. L. (2004). Ecological systems approach. [internet] Retrieved from http//:www.users.global net.co.uk/ ebstudy/strategy/ecosys.htm.

Bitter, J. R. (2014). Theory and practice of family therapy and counseling (2nd ed.). Belmont, CA: Brooks/Cole, Cengage Learning.

Bozdağ, Y. (2018). Film analizi yöntemi ile aile terapileri: Gilbert'in hayalleri. Yaşam Becerileri Psikoloji Dergisi, 2(3), 87-95. doi: 10.31461/ybpd.430396

Brody, G. H., Stoneman, Z. \& McCoy, J. K. (1994). Forecasting sibling relationships in early adolescence from child temperaments and family process in middle childhood. Child Development, 65, 771-784. doi: $\underline{10.2307 / 1131417}$

Cag, P. \& Voltan Acar, N. (2015). A view of the symbolicexperiential family therapy of Carl Whitaker through movie analysis. Educational Sciences: Theory and Practice, 15(3), 575-586. doi:10.12738/estp. 2015.3.2477

Dermer, S. B. \& Hutchings, J. B. (2000). Utilizing movies in family therapy: applications for individuals, couples, and families. The American Journal of Family Therapy, 28, 163-180. doi: $\underline{10.1080 / 019261800261734}$

Figley, C. R. \& Nelson, T. S. (1990). Basic family therapy skills: structural family therapy, Journal of Marital and Family Therapy, 16, 225-239. doi: 10.1111/j.1752-0606.1990.tb00845

Gehart, D. R. (2016). Theory and treatment planning in family therapy: A competency-based approach. Boston, MA: Cengage Learning.
Gladding, S. T. (2011). Aile terapisi: Tarihi, kuram ve uygulamaları. Ankara: Atalay Matbaacılik.

Goldenberg, I. \& Goldenberg, H. (2008). Family therapy: An overview. USA: Thomson/Brooks Cole Pub.

Lee, Y. (2011). Structural family therapy. marriage and family therapy. A practice-oriented approach. L. Medcalf (Ed.). New York: Springer Publishing Company.

Mert, A. \& Soyer, B. (2014). "Kevin Hakkında Konuşmalıyız" filminin Bowlby'nin çocukluk dönemi bağlanma stilleri ve Minuchin'in yapısal aile sistemleri yaklaşımı temel kavramları kullanılarak değerlendirilmesi. OPUS Uluslararast Toplum Araştırmaları Dergisi, 4(7), 100-115.

Miles, M. B. \& Huberman, A. M. (1994). Qualitative data analysis: An expanded sourcebook. CA: Sage Pub.

Minuchin, S. (1974). Families and family therapy. Cambridge: Harvard University Press.

Minuchin, S. (1981). Constructing a therapeutic realty. Annual review of family therapy. G. Brenson ve $\mathrm{H}$. White (Ed). pp. 129-147. New York: Human Sciences Press.

Minuchin, P., Colapinto, J. \& Minuchin, S. (2007). Working with families of the poor. NewYork London: The Guilford Press.

Nadir, U. (2013). Aile danışmanlığı eğitiminde popüler filmlerin kullanımı ve yapısal aile terapisi kuramı ile dalgaların prensi filminin analizi. Toplum ve Sosyal Hizmet, 24(1), 129-143.

Nazlı, S. (2016). Aile danışmanlığ

Nichols, M. P. (2013). Aile terapisi kavramlar ve yöntemler. İstanbul: Kaknüs Yayıncılık.

Rasheed, M., Rasheed, N. \& Maley, J. A. (2011). Family therapy. Models and tecniques. USA: Sage.

Sharf, R. S. (2010). Theories of psychotherapy and counseling: Concepts and cases. USA: Brooks/Cole.

Shepard, D. S., \& Brew, L. (2005). Teaching theories of couples counseling: The use of popular movies. The Family Journal, 13(4), 406-415. doi: 10.1177/ 1066480705278470

Şenol-Durak, E. \& Fişıloğlu, H. (2007). Film analizi yöntemi ile Virginia Satir aile terapisi yaklaşımına bir bakış. Türk Psikoloji Yazıları, 10(20), 43-62.

Tanner, L R., Haddock, S. A., Zimmerman, T. S. \& Lund, L. K. (2003). Images of couple and families in disney feature-length animated films. The American Journal of Family Therapy, 31, 355-373. doi: $\underline{10.1080 / 01926180390223987}$

Wetchler, L. J. (2003). Structural family therapy. An indroduction to marriage and family theraphy. L. L. Hecker ve L. J. Wetchler (Ed.). pp. 63-94. New York: The Haworth Clinical Practice Press.

White, J., Klein, D. \& Martin, T. (2015). Family theories. Thousand Oaks, CA: Sage Publications. 
Whiteside, D. (1994). Using family therapy concepts to teach organizational behavior. Journal of Management Education, 18(1), 86-97. doi: $\underline{10.1177 /}$ $\underline{105256299401800107}$

Yağbasan, M. ve Ateş, U. (2018). 1980 Öncesi Ve 2000 Sonrası Türk Sinemasında Ailenin Temsili. Akademik Bakış Dergisi, 67(2), 26-40.
Yıldırım, A. \& Şimşek, H. (2013). Sosyal bilimlerde nitel araştırma yöntemleri. Ankara: Seçkin Yayıncılık.

Yıldız, M. (2017). Yapısal aile terapisinin temel kavramlariyla gelin filminin incelenmesi. Uluslararası Toplum Araştırmaları Dergisi, 7(12), 157-176. doi: 10.26466/opus.285054 